Since the outbreak of the War this bibliographic work has found and met an increased demand; an extensive annotated bibliography on steel sheet and strip issued in three parts has been in particularly heavy request from other parts of Great Britain and from overseas. Encouraged by this demand from a wider area, the City Librarian has prepared a list of recently compiled bibliographies; the subjects at present available include : acid tanks; austenit:c steels ; auto-frettage process ; bending, straightening and reeling of steel; bonus systems ; cold drawing of steel ; cold heading of steel ; cold pressing : colloidal metals; colouring of metals ; decarburization of metals by hydrogen; electrolytic pickling and polishing; extrusion of steel ; fatigue of metals ; fluorspar-froth flotation; ingots: segregation and crystallization; patents on rock drill bits; manufacture of steel tubes; polarography; riveting of steel ; rolling mills; spinning of steel ; steel manufacture and properties; sulphur and phosphorus determination in iron and steel ; tool steels; vertical boring mills; workshop practice and machine tools (books only). Applications for copies of any of the lists should be sent, with $3 d$. to cover postage, to the Central Library, Sheffield, 1.

\section{The Lister Institute of Preventive Medicine}

THough damaged on two occasions and partly evacuated, the Lister Institute of Preventive Medicine has spent an active year, as shown by its annual report. As usual, the work has covered a wide field, including studies on antigens, phosphorylation in osteoid tissue, fat metabolism, and mucolytic enzymes. The Division of Nutrition, working at Cambridge and East Malling, has continued its vitamin studies. The Cambridge group has in particular investigated the nutritive value of different portions of the wheat grain and has been instrumental in recommending the use of 85 per cent extraction flour with added calcium for bread-making; the national wheatmeal flour is of this extraction, but the decision to add calcium to it has not yet been taken. The nutritive value of yeast has also been investigated, and this work is of particular import? nce since it is easy to grow yeast on certain waste materials, thereby providing a human food rich in first-class protein and vitamins of the B group. Dr. Zilva, at East Malling, has continued his work on vitamin $\mathrm{C}$.

\section{The Henry Lester Institute of Medical Research}

The Henry Lester Institute of Medical Research, Shanghai, has also recently issued its annual report, and this shows that all ac:ivities have had to be restricted owing to the war in China. Studies on nutrition occupy a large part of the report, and Prof. Earle, who has recently been visiting Great Britain, states that "it is remarkable how many clinical signs and symptoms among Chinese patients can now be explained in terms of vitamin and mineral deficiency". Apart from many cases of two classical deficiency diseases-beriberi and pellagrait has recently been found that ariboflavinosis is very common among the Chinese : more than a hundred cases were investigated during the latter part of the year. Deficiency of riboflavin is the latest recruit to human deficiency diseases, and has been shown by Sebrell to be surprisingly common in the United States. The condition, which includes eye and mouth lesions, undoubtedly occurs also in Great Britain.

\section{Winter Wheat Seed}

THE Council of the National Institute of Agricultural Botany, Cambridge, has decided to offer for sale about a hundred quarters of Steadfast, a winter wheat bred by Prof. F. L. Engledow, of the Cambridge University Plant Breeding Institute. Hitherto the wheat has been grown in the Institute's trials under the number $198(20 c)$. Orders are invited from members of the Agricultural Seed Trade Association, National Association of Corn and Agricultural Merchants, National Association of British and Irish Millers, and other established dealers in seed corn. Steadfast is the outcome of a cross between Little Joss and Victor, and as regards general habit, growth and type of ear is intermediate between the parent varieties. It possesses the excellent tillering properties of Little Joss, and ripens at the same time, and requires the same seed rate. The straw is shorter and its resistance to lodging is superior to that of Little Joss, but it has the same resilience and excellent thatching and feeding properties of that variety. As regards milling quality, Steadfast approximates the bread-making value of the 'softer' English wheats; it does not attain the exceptional quality of Yeoman or Holdfast. It is particularly suited to light and medium soils, but also thrives on the Black Fen, where its resistance to yellow rust will be specially valuable.

\section{A Film Studio Electrical Installation}

Mr. F. V. HAUSER, chief engineer of two studio groups at Denham (Uxbridge, Middlesex) and Pinewood (Iver, Bucks), comprising twelve stages with a plant capacity of $7,000 \mathrm{kw}$., recently gave an illustrated lecture about studios to the Association of Supervising Electrical Engineers in London. Confining his detailed description to the Pinewood installation, Mr. Hauser said that the maximum electric demand for studio photographic purposes approximated to $2,000 \mathrm{kw}$. As D.C. at low voltage is necessary for arc lighting, five electric diesel generators totalling $2,360 \mathrm{kw}$. have been installcd with three-wire distribution at $230 / 115 \mathrm{v}$. for studio lighting and at $230 \mathrm{v}$. only for all other purposes. To reduce noise and vibration, the engine foundations were formed of single island rafts of concrete $2 \mathrm{ft}$. thick, set $9 \mathrm{ft}$. below floor level and covered with a 2.5 inch sandwich of 'Coresil' cork on which rested a common concrete block $7 \mathrm{ft}$. deep, the whole weighing 1,000 tons. The insulating air space around the foundation is $9 \mathrm{in}$. wide.

To minimize voltage ripple (hum) interfering with sound recording, the generators have graded air gaps, specially shaped pole faces and skewed armature 